\title{
CONHECIMENTO TESTEMUNHAL - A VISÃO NÃO REDUCIONISTA
}

\author{
KNOWLEDGE BY TESTIMONY \\ - THE NON-REDUCTIONIST VIEW
}

Felipe de Matos Müller*

RESUMO - Neste ensaio, consideramos a possibilidade de o conhecimento ser transmitido ou transferido via testemunho. Apresentamos inicialmente uma introdução à epistemologia do testemunho, indicando a sua origem em uma tradição que tem John Locke, David Hume e Thomas Reid como seus representantes. Apresentamos uma versão da tese não-reducionista. Mostramos que o não-reducionista acerca do conhecimento testemunhal deve requerer um desempenho epistêmico conducente à verdade por parte do falante e a integridade intelectual do ouvinte.

PALAVRAS-CHAVE - Crença baseada no testemunho. Conhecimento testemunhal. Não-reducionismo.

ABSTRACT - In this essay we consider the possibility of knowledge being transferred or transmitted via testimony. Initially, we present an introduction to the epistemology of testimony, by indicating their origin in a tradition that has John Locke, David Hume and Thomas Reid as their representatives. We present a version of the non-reductionist thesis. We show that the non-reductionist about knowledge must request from the speaker a testimonial epistemic performance that is truth conductive, as well as intellectual integrity from the listener.

KEYWORDS - Testimony-based beliefs. Testimonial knowledge. Nonreductionism.

\section{Introdução}

Pessoas invariavelmente não aprendem a falar ou a pensar sem a ajuda de outros. Muitas das crenças de uma pessoa dependem pelo menos em

* Doutor em Filosofia pela PUCRS. Professor no PPG em Filosofia da PUCRS.

\begin{tabular}{|l|l|l|l|l|l|}
\hline Veritas & Porto Alegre & v. 55 & n. 2 & maio/ago. 2010 & p. 126-143 \\
\hline
\end{tabular}


parte do testemunho de alguém. O filósofo escocês David Hume chegou a afirmar que "não há tipo de raciocínio mais comum, mais útil e mesmo mais necessário à vida humana que o derivado do depoimento humano" (HUME, EEH, X). Embora possa haver algo que pessoas possam saber sem o testemunho, parece difícil pensar a vida cotidiana sem ele. Robert Audi aponta a razão da indispensabilidade epistêmica do testemunho, quando declara que:

Pode ser que nenhum ser humano normal viesse a conhecer coisa alguma, se não fosse através do testemunho. Se não existe conhecimento inato e se ninguém viesse a conhecer alguma coisa antes do aprendizado de uma língua (...), então, a menos que alguém pudesse adquirir competência linguística sem a ajuda dos outros, eles seriam essenciais para que alguém viesse a conhecer qualquer coisa. (AUDI, 2003, p. 146.).

Afinal, o imenso corpo de informações acumuladas e compartilháveis que possuímos sobre o mundo, que constitui o núcleo de nosso legado científico-cultural e que não só permite orientar as nossas ações, mas nos fornece algum poder sobre o próprio mundo, foi-nos transmitido pelo testemunho dos outros. Coady comenta que:

Muitos de nós nunca viram um bebê nascer, muitos de nós tampouco examinaram a circulação do sangue, nem a atual geografia do mundo, nem examinaram as leis do país, nem têm feito observações que estão além do nosso conhecimento, como a de que as luzes no céu são corpos celestes imensamente distantes [...] (COADY, 1992, p. 82.).

Frederick Schmitt (1999) assinala que "sempre se reconheceu que as condições sociais dão suporte ao conhecimento" e que "as pessoas não podem adquirir muito conhecimento sem a linguagem socialmente dada". Aliás, não há controvérsia em afirmar que "aprendemos o conceito de conhecimento [...] de outros". A avaliação feita sobre nossas crenças e opiniões "é um ato socialmente dirigido, uma vez que avaliamos os estados cognitivos dos outros".

Entretanto, o interesse pelo testemunho na história da epistemologia é bastante recente. Frederick Schmitt (1999) comenta que o interesse pelo estatuto epistêmico do testemunho foi aumentando durante os séculos 17 e 18, sobretudo, na medida em que a sua compreensão se dissociava do discurso religioso, muito proeminente durante o medievo. Um fato paralelo foi a ascensão do estatuto da percepção e das crenças baseadas na percepção em virtude da nova ciência que surgia. Nesse contexto, comenta ainda Schmitt, o testemunho não foi apenas associado à percepção, mas também subjugado por ela. O motivo foi 
que a confiabilidade da percepção não precisava ser verificada, mas a confiabilidade do testemunho necessitava. Esses fatores favoreceram a compreensão da existência de uma assimetria entre o testemunho e a percepção. A conseqüência disso foi que a justificação testemunhal se tornou derivada da justificação perceptiva.

\section{A origem do debate}

Três filósofos podem ilustrar as principais visões acerca do testemunho durante os séculos 17 e 18. Eles são John Locke (1632-1704), David Hume (1711-1776) e Thomas Reid (1710-1796). Compreender as características principais dessas três visões pode iluminar a nossa compreensão de algumas posições contemporâneas. Entretanto, não há aqui espaço para fazer uma investigação histórica. O objetivo a ser alcançado na abordagem que segue não é mais que apontar uma direção, mas uma direção importante, que leva ao coração da discussão sobre a epistemologia do testemunho.

John Locke defendeu a opinião de que as outras pessoas não são fontes de conhecimento. Ainda que alguém diga a verdade, alguém não poderia obter conhecimento meramente por causa disso. John Locke depreciou a prática de confiar no testemunho. Richard Foley (2001, p. 89) comenta que Locke "repetidamente insiste que, no processo de regulação do parecer, os apelos à autoridade intelectual de terceiros devem ser evitados. Locke deixa clara a sua posição, quando afirma que:

"Não é que me falte respeito devido pelas opiniões alheias; mas, ao fim e ao cabo, é à verdade que devemos o maior respeito. E espero que não me acusem de arrogante por dizer que mais adiantaremos no conhecimento se o procurarmos na fonte, na consideração das próprias coisas; e mais usando bem o nosso pensamento do que servindo-nos do pensamento dos outros. (...) O fato de nos nossos cérebros circularem opiniões de outras pessoas, ainda que sejam verdadeiras, não nos torna mais conhecedores." (LOCKE, E.E.H., 1.4.24.).

O que concede o mérito ao agente é crer ou deixar de crer segundo o comando da sua razão. Parece ser importante, para Locke, não correr riscos quando se trata do empreendimento epistêmico. Para Locke, alguém deve crer somente quando tem boas razões. Aquele que não faz assim, ele diz, "vai contra a sua própria luz e usa de maneira errada aquelas faculdades que lhe foram dadas".

A posição adotada por John Locke é caracterizada por Frederick Schmitt (1994, p. 5) como individualismo forte acerca do testemunho. No entanto, Locke focaliza mais sobre a noção de conhecimento do que sobre a 
noção de justificação, como comenta Schmitt. Para Locke, o conhecimento é adquirido de modo autônomo. Todo o conhecimento que alguém pode adquirir tem a sua fonte e base em suas próprias possibilidades cognitivas; nenhuma crença pode estar baseada epistemicamente no testemunho, mas em fontes não-testemunhais, como a perceptual, a memorial e a inferencial. Locke considera desprezível a atitude daquele que menospreza as vantagens das capacidades que recebeu. Na Carta ao Leitor chega a declarar que "não vale a pena se preocupar com o que disse ou pensa quem diz ou pensa tão somente de acordo com a orientação de outrem". Entretanto, uma objeção que se ergue rapidamente é que ela abre caminho para algum tipo ceticismo, visto que exclui se conhecimento implica justificação - conhecimento sobre algumas informações, como, por exemplo, da própria data de nascimento e da própria história familiar.

David Hume, em seu An Enquiry Concerning Human Understanding, assumiu a posição de que poderíamos confiar nos relatos dos outros, desde que tivéssemos razões para crer, baseadas em nossas observações pessoais, que as fontes fossem confiáveis. Hume assume uma posição radicalmente diferente daquela de Locke. David Hume reconhece a importância e a necessidade do testemunho dos outros para o empreendimento investigativo. Entretanto, essa abertura à dimensão social do conhecimento deve ser regulada pela experiência individual. O investigador é um agente epistêmico completamente autônomo. Cito Hume:

“[...] ninguém pode depositar, em relação aos seus testemunhos, a mesma confiança que tem em relação ao objeto imediato de seus sentidos. Mas uma evidência mais fraca nunca pode destruir uma mais forte; [...] Um homem sábio, portanto, torna sua crença proporcional à evidência. [...] Aplicando estes princípios a um caso particular, constatamos que não há espécie de raciocínio mais comum, mais útil e mesmo mais necessário à vida humana que o derivado do depoimento humano, dos relatos das testemunhas oculares e dos expectadores. Negar-se-ia, talvez, que esta espécie de raciocínio se funda na relação de causa e efeito. Não discutirei sobre a terminologia. Será suficiente notar, contudo, que nossa segurança em qualquer argumento deste gênero não deriva de outro princípio senão da constatação da veracidade do testemunho humano e da conformidade usual dos fatos com os relatos das testemunhas." (HUME, Investigação, Seção X).

A posição adotada por David Hume é caracterizada por Frederick Schmitt (1994, p. 5) como individualismo fraco acerca do testemunho. Para Hume, crenças baseadas no testemunho só alcançam um estatuto epistêmico positivo se estiverem baseadas em fontes individuais, como a 
percepção, o raciocínio, etc., segundo as quais o testemunho é confiável ou digno de crédito. Para que um sujeito possa aceitar a declaração de outra pessoa, ele deveria primeiro constatar a veracidade do testemunho e a conformidade usual dos fatos com os relatos das testemunhas. Todavia, sem essa constatação, não se está epistemicamente autorizado a aceitar o relato de outra pessoa. A constatação requerida por Hume funciona como um filtro. Esse filtro protegeria da desatenção, da credulidade ou do rigor excessivo produzido pelo ceticismo.

Thomas Reid, em seu An Inquiry into the Human Mind on the Principles of Common Sense, em meados do século 18, considerou de modo efetivo a possibilidade de o testemunho desempenhar um papel epistemológico primário, e não apenas secundário. Entretanto, o ponto central da abordagem de Reid parece ser a de que ele vê o agente epistêmico em meio a relações sociais. Nicholas Wolterstorff comenta que "a importância da discussão de Reid sobre o testemunho é que nessa discussão há uma imagem diferente elaborada - uma imagem da pessoa como um ser social" (WOLTERSTORFF, 2001, p. 165). Esta posição pode ser explicitada, quando Thomas Reid afirma que:

"O sábio e beneficente Autor da Natureza, o qual pretendeu que fossemos criaturas sociais e que recebêssemos a maior e mais importante parte do conhecimento por meio das informações dos outros, para esses propósitos, introduziu em nossa natureza dois princípios que coincidem um com o outro" (REID, IHM VI, xxiv [196a; B 193]).

Thomas Reid sustentou que o testemunho dos outros - ou, ao menos, o testemunho sincero - é prima facie crível, mesmo quando não se tem razões independentes em favor da confiabilidade da testemunha. Reid pensava que, se as atitudes naturais de confiança mútua não fossem razoáveis, o resultado inevitável seria o ceticismo. Ele colocou a justificação testemunhal como um "primeiro princípio". Esse primeiro princípio está baseado em duas disposições inatas: (a) veracidade ou disposição para falar a verdade e (b) credulidade ou disposição para acreditar no que os outros dizem. A proposta de Reid amplia ainda mais a proposta de Hume acerca da aquisição de conhecimento através do testemunho. Ela estabelece as bases e sugere a possibilidade de uma confiança inicial, de forma irrestrita, no relato de alguém.

\section{Reducionismo versus não-reducionismo}

Um dos pontos que surge da discussão contemporânea sobre a epistemologia do testemunho é explicar o que confere o estatuto de justificada a uma crença baseada no testemunho. Uma visão extensa e 
detalhada sobre o assunto pode ser encontrada, sobretudo, nas obras de C. A. J. Coady (1992) e Jennifer Lackey (2008). Entretanto, nesta seção, tentarei caracterizar, de forma breve e apenas introdutória, as grandes posições sobre a epistemologia do testemunho: o reducionismo e o nãoreducionismo.

O reducionismo, cujas raízes históricas remontam a David Hume, requer que uma base não-testemunhal suficiente seja oferecida pelo agente epistêmico, isto é, exige que os ouvintes tenham razões positivas para verificar a credibilidade dos informantes. A tese das razões positivas postula que uma crença baseada no testemunho está justificada somente se ela estiver baseada em razões positivas por parte dos ouvintes, isto é, por razões que não podem elas mesmas estar baseadas no testemunho, evitando, assim, o estabelecimento de uma circularidade. Nesse sentido, requer-se que o ouvinte produza inferências indutivas, com base em sua experiência, sobre a competência do declarante ou sobre a probabilidade das declarações. Existem duas versões do reducionismo: o global e o local. O reducionismo global requer que o ouvinte ofereça uma base nãotestemunhal (perceptual, memorial ou inferencial indutiva) suficiente em apoio a todas as suas crenças baseadas no testemunho, a fim de que as mesmas possam estar justificadas. O reducionismo local requer que o ouvinte ofereça uma base não-testemunhal (perceptual, memorial ou inferencial indutiva) suficiente em apoio apenas àquela crença baseada no testemunho que está em questão, a fim de que a mesma possa estar justificada.

O não-reducionismo, cujas raízes históricas remontam a Thomas Reid, não requer que uma base não-testemunhal suficiente seja oferecida pelo agente epistêmico, bastando que não exista qualquer base epistêmica para a dúvida, quer seja sobre a credibilidade do falante quer seja sobre a declaração em questão. O não-reducionismo requer do ouvinte que ele não tenha qualquer derrotador não-derrotado (undefeated defeater) sobre as declarações do falante. Existem dois tipos de derrotadores: os psicológicos e os normativos. Um derrotador psicológico pode ser uma dúvida ou uma crença mantida pelo ouvinte que indica que a proposição declarada pelo falante é falsa ou inconfiavelmente formada (ou sustentada). Um derrotador normativo é uma dúvida ou crença que o ouvinte deveria ter e que indicaria que a proposição declarada pelo falante é falsa ou inconfiavelmente formada ou sustentada.

Se, por um lado, pode-se dizer que o não-reducionismo não exige razões para pensar que uma instancia particular do testemunho seja verdadeira, por outro lado pode-se dizer que o reducionismo parece intelectualizar demasiadamente a noção de justificação de uma crença baseada no testemunho. Afinal, exigir que toda crença baseada no testemunho 
seja checada por meio da percepção, da memória ou do raciocínio, por exemplo, é exigir mais do que seres humanos são igualmente capazes de fazer. É praticamente impossível checar em primeira mão mais que uma minúscula fração das informações obtidas pelo testemunho. Assumir essa posição seria intelectualizar a noção de justificação sobre crenças baseadas no testemunho. A justificação de crenças baseadas no testemunho deve depender daquilo que seres humanos são igualmente capazes de fazer.

\section{Não-reducionismo}

O meu propósito nesta seção é avaliar de modo particular a visão não-reducionista acerca do conhecimento testemunhal. Assumirei como ponto de partida a visão de Robert Audi (2003) sobre o conhecimento testemunhal para estabelecer uma visão padrão. Depois, avaliarei o papel requerido do falante e, posteriormente, o papel requerido do ouvinte.

Crianças em seus primeiros anos de vida dependem quase totalmente do testemunho de seus pais, benfeitores e tutores para aprender sobre o mundo. Todavia, crianças são incapazes de verificar a confiabilidade do testemunho. Inicialmente, elas não têm uma base experiencial suficiente para estarem justificadas em crer que os seus pais, benfeitores, tutores e outros adultos são dignos de confiança. Se aceitássemos o testemunho apenas sob a condição da verificação, então crianças pequenas teriam que avaliar a confiabilidade das fontes dos testemunhos antes de crer nos relatos que lhe são oferecidos. Entretanto, crianças pequenas nem sequer têm o conceito de credibilidade e outras noções importantes para poderem avaliar as fontes testemunhais. Robert Audi parece seguir está mesma linha quando afirma que:

"Muito cedo em suas vidas, falamos de bebês e crianças conhecerem as coisas. [...] Apesar de tudo, podemos certamente falar de seu aprendizado - que o leite derrama quando derrubado, que o fogão está quente, e assim por diante - e que aprendizagem (em geral) implica conhecimento. [...] Se, como parece razoável supor, ganhar conhecimento baseado no testemunho requer apenas não ter razões para duvidar da credibilidade da testemunha, então a visão proposta acima não encontra dificuldades." (AUDI, 2003, p. 144).

Uma formulação inicial do não-reducionismo em relação ao conhecimento testemunhal pode ser descrita da seguinte forma (LACKEY, 2008):

NR: Para um falante A e um ouvinte B, B sabe que $p$ com base no testemunho de $A$ de que $p$ se e somente se: 
$\left(\mathrm{NR}_{1}\right)$ B crê que $p$ por causa e com base no testemunho de A de que $p$;

$\left(\mathrm{NR}_{2}\right) \quad B$ não tem qualquer derrotador não-derrotado (psicológico ou normativo) para o testemunho de A de que $p$; e

$\left(\mathrm{NR}_{3}\right) \quad p$ é verdadeira.

Considerarei apenas casos em que o falante A declara (verbalmente ou por escrito) que $p$. Não pretendo discutir, aqui, a natureza do testemunho. Entretanto, assumirei como pressuposto a visão de que testemunhar é o "ato de contar, incluindo todas as declarações que aparentemente destinam-se a transmitir informações, apesar do contexto social" (FRICKER, 1999, p. 909.). Assim, quando alguém consulta um mapa rodoviário, antes de sair de férias, para orientar-se durante uma viagem, ele está confiando no testemunho do cartógrafo. Quando alguém lê no jornal a previsão do tempo para os próximos dias, ele está confiando no testemunho dos meteorologistas. Cada vez que alguém forma alguma crença com base no que leu em um mapa, jornal, livro ou revista, ou com base no que ouviu de seus pais, de um amigo, do seu professor, ou de outros, seja diretamente ou por meio da TV, rádio ou internet, está confiando na palavra dos outros.

A condição $\mathrm{NR}_{1}$ é a condição da crença baseada no testemunho. Assumirei, aqui, que crenças baseadas no testemunho são aquelas que (a) foram diretamente formadas em resposta ao testemunho e que (b) são sustentadas exclusivamente pelo testemunho.

A condição $\mathrm{NR}_{2}$ é caracterizada como uma exigência negativa. Ela requer apenas a ausência de derrotadores não-derrotados. Esta condição é mais fraca que a exigência de razões positivas requerida pelos reducionistas. Uma condição para rejeitar o testemunho de alguém é que o ouvinte tenha alguma crença justificada contra a credibilidade do informante ou contra a probabilidade da proposição declarada ser verdadeira. Robert Audi compartilha dessa visão, quando afirma que:

"Com certeza, o testemunho pode ser derrotado - impedido de produzir conhecimento no receptor - através de crenças justificadas de alguma proposição contrária ao que foi atestado. Mas, na ausência de tais crenças contrárias, o beneficiário adquire o conhecimento baseado no testemunho." (AUDI, 2003, p. 145).

A condição $\mathrm{NR}_{3}$ está aí para distinguir conhecimento testemunhal de justificação testemunhal. De acordo com NR qualquer relato verdadeiro de qualquer falante pode proporcionar conhecimento testemunhal para qualquer ouvinte, caso não haja algum derrotador não-derrotado. A visão apresentada por NR sugere uma grande abrangência. Vou me concentrar 
inicialmente em avaliar um relato verdadeiro de qualquer falante. Uma criança ou um adulto, um amigo ou um completo desconhecido poderiam exemplificar qualquer falante.

Considere o caso do pedido de informação. Suponha que você está conduzindo o seu carro em direção ao litoral, mas não sabe onde fica a entrada da praia em que deseja veranear. De repente, à margem da estrada, você avista alguém (um estranho), pára o carro e pergunta: "Onde é a entrada para a praia...?". Ocorre que o sujeito lhe fornece a informação $p$. Naquela situação, você passa a crer que $p$ por causa e com base no que aquele estranho lhe disse, e não possui qualquer derrotador não-derrotado. Suponha, ainda, que seja fato que $p$.

O primeiro aspecto a considerar, nesse caso, é que o informante é um completo estranho. O fato de você saber que já está na região litorânea e relativamente perto do seu destino, quando você encontra o informante, não parece ser suficiente para que você saiba algo sobre os hábitos epistêmicos dele. Ele poderia habitar por perto e conhecer a região, mas também poderia habitar por perto sem conhecer bem a região. Afinal, tantas pessoas têm uma rotina diária de atividades cujo espaço de circulação é limitado. Por causa disso, muitas delas sequer conhecem aquelas ruas próximas dos lugares que costumam frequentar. Outra hipótese é a de que o informante habite a região há muito pouco tempo e, por causa disso, ainda não tenha tido tempo e oportunidade suficientes para conhecer melhor o lugar. $O$ fato de o informante ter sido simpático e lhe ter oferecido prontamente uma resposta à sua pergunta não lhe fornece qualquer indicação suficiente e relevante sobre os seus hábitos epistêmicos.

O segundo aspecto a observar, nesse caso, é que, por algum motivo, você pára o carro e faz uma pergunta a alguém. O objetivo padrão, ao perguntar algo a alguém, é o de obter do interlocutor a informação verdadeira. Nesse sentido, perguntar algo a alguém implica uma atitude de deferência, por parte de quem pergunta, à opinião do interlocutor. No caso do pedido de informação, o fato de você pedir alguma informação parece conceder alguma autoridade epistêmica ao informante, antes mesmo de ter alguma informação sobre as suas opiniões ou os seus hábitos epistêmicos. O fato de o ouvinte conceder tal autoridade epistêmica pressupõe uma atitude de confiança intelectual inicial em relação ao informante. Quando se confia intelectualmente em alguém, normalmente acredita-se no que ele declara, a menos que se tenha alguma razão para pensar que as suas declarações estejam além de sua competência intelectual.

Você pode pensar que é mais razoável obter alguma informação de um estranho do que manter-se na ignorância. Entretanto, considerando 
o ideal epistêmico (maximizar a verdade e minimizar a falsidade em um amplo corpo de crenças), devemos confiar naqueles meios que sejam conducentes à verdade, ou seja, devemos confiar em pessoas que muito provavelmente digam a verdade. Porém, confiar em um estranho parece não ser um meio eficaz para maximizar o ideal epistêmico. O que você deve considerar é que, ao perguntar algo a algum estranho, ao perguntar algo a alguém no qual você não tem qualquer indicação de que lhe dará uma resposta verdadeira, você está tomando uma atitude que não promove o fim epistêmico ou está assumindo que as pessoas são em princípio verazes. Entretanto, NR afirma que o relato verdadeiro de qualquer falante, veraz ou mentiroso, pode proporcionar conhecimento testemunhal para qualquer ouvinte, caso não haja algum derrotador não-derrotado.

Agora, alteraremos o caso inicial a fim de compreendermos melhor o problema. Considere agora o caso do transeunte mentiroso. Suponha que você esteja conduzindo o seu carro em direção ao litoral, mas não sabe onde fica a entrada da praia em que deseja veranear. De repente, à margem da estrada, você avista alguém (um estranho), pára o carro e pergunta: "Onde é a entrada para a praia...?". Ocorre que o sujeito lhe fornece a informação $p$. Naquela situação, você passa a crer que $p$ por causa e com base no que aquele estranho lhe disse e não possui qualquer derrotador não-derrotado. Suponha que seja fato que $p$. E suponha, ainda, que o estranho é na verdade um transeunte mentiroso que, ao tentar enganá-lo, sem ter qualquer conhecimento da região, acidentalmente lhe deu a informação verdadeira.

Considere que todas as condições de NR foram satisfeitas: você passou a crer que $p$ por causa e com base no testemunho daquele estranho de que p. A condição $\left(\mathrm{NR}_{1}\right)$ foi satisfeita. O informante é um transeunte mentiroso, mas você não tem qualquer indicação dos hábitos epistêmicos dele. Você teve contato com ele por apenas poucos segundos, apenas durante o tempo de fazer a pergunta e ouvir a resposta. Você não tem qualquer crença sobre os hábitos epistêmicos particulares daquele informante. $\mathrm{O}$ que você poderia ter é a crença de que as pessoas geralmente são verazes. Você não tinha e não passou a ter qualquer crença justificada que desempenhasse o papel de um derrotador não-derrotado (psicológico ou normativo) para o testemunho do informante de que $p$. A condição $\left(\mathrm{NR}_{2}\right)$ foi satisfeita. Ocorre, no entanto, que é fato que $p$. A condição $\left(\mathrm{NR}_{3}\right)$ foi satisfeita. Entretanto, ela foi satisfeita de modo completamente acidental. De acordo com NR, se as condições $\mathrm{NR}_{1}-\mathrm{NR}_{3}$ foram satisfeitas, então o ouvinte sabe que $p$. Dado o caso do transeunte mentiroso, você deveria saber que $p$. Entretanto, parece-me que você não sabe que $p$. O informante não sabia que $p$, era completamente inconfiável, tentava 
lhe enganar e, por um fato completamente acidental, ele lhe ofereceu a informação verdadeira.

Considere agora uma variante do caso do transeunte mentiroso II. Suponha que você esteja conduzindo o seu carro em direção ao litoral, mas não sabe onde fica a entrada da praia em que deseja veranear. De repente, à margem da estrada, você avista alguém (um estranho), pára o carro e pergunta: "Onde é a entrada para a praia...?". Ocorre que o sujeito lhe fornece a informação $p$. Naquela situação, você passa a crer que $p$ por causa e com base no que aquele estranho lhe disse e não tem qualquer derrotador não-derrotado. Suponha que seja fato que $p$. Contudo, suponha, ainda, que o estranho seja na verdade um transeunte mentiroso, que havia chegado à região há uma semana e que aplicou todas as mentiras que pudera nos habitantes do povoado. Por causa disso, já havia circulado pelas redondezas e conhecia praticamente todas as ruas. Quando você perguntou "Onde é a entrada para a praia...?", ele já estava cansado de ter enganado tanta gente. Como havia percorrido todas as ruas, ele sabia qual era a rua certa. Portanto, o transeunte mentiroso sabia que $p$, forneceu-lhe a informação que $p$, e era fato que $p$. O que dizer agora? Dado o caso do transeunte mentiroso, você viria a saber que $p$, por causa do e com base no testemunho dele? Também nesse caso, parece-me que não. Você não viria a saber que $p$. A questão não é se o informante tem, ou não, conhecimento, ou até mesmo se pode adquirir conhecimento. A questão é se ele pode transmiti-lo ou transferi-lo adequadamente. Lembre-se que assumi que crenças baseadas no testemunho são aquelas que (a) foram diretamente formadas em resposta ao testemunho e que (b) são sustentadas exclusivamente pelo testemunho. A sua crença foi formada em resposta à declaração de um estranho, que, sem que você saiba, é um mentiroso - um mentiroso que sabe que $p$. Obter uma informação, ainda que verdadeira, de um mentiroso, é algo improvável. Um mentiroso não é uma fonte confiável. Perguntar algo a um mentiroso não é um meio eficaz para maximizar o ideal epistêmico. Nesse caso, parece-me que você não saberia que $p$. A base que sustenta a sua crença não é conducente à verdade. Note que não é suficiente que o informante saiba que $p$. Não é o caso que, para um falante $A$ e um ouvinte $B$, se A sabe que $p$, B crê que $p$ com base no testemunho de $\mathrm{A}$ de que $p$ e B não têm qualquer derrotador não-derrotado, então B sabe que $p$. Além de considerar se o informante sabe que $p$, existe outro aspecto crucial, se o informante é veraz ou é um transmissor confiável. Pode-se pensar em vários casos em que o informante sabe que $p$, mas sofre de algum distúrbio, de alguma debilidade ou coerção e, por causa disso, passa a ser um transmissor inconfiável. Segue-se disso que requerer conhecimento do falante não é suficiente para obter uma atitude conducente à verdade 
por parte do mesmo. Entretanto, dever-se-ia pensar se o requerimento de conhecimento por parte do falante não é uma condição necessária para que o ouvinte obtenha conhecimento por meio do testemunho.

Há uma visão sobre a transmissão ou a transferência do conhecimento, que, frequentemente, está apoiada em uma analogia entre o testemunho e a memória. Diz-se que, assim como a memória preserva conhecimento de um momento para o outro, analogamente o testemunho transfere ou transmite conhecimento de uma pessoa para outra. Se uma pessoa sabe, no tempo $t^{2}$, com base na memória, que o almoço na última segunda-feira foi servido pontualmente às $12: 00 \mathrm{hs}$, então é porque, no tempo $\mathrm{t}^{1}$, essa mesma pessoa tinha conhecimento memorial de que o almoço na última segunda-feira fora servido pontualmente às 12:00hs. Analogamente, se venho a saber que o time de futebol " $\mathrm{X}$ " ganhou a última partida do campeonato, com base no testemunho de uma pessoa (pode ser um amigo ou um desconhecido), então é porque essa pessoa sabia que o time de futebol " $X$ " ganhara a última partida do campeonato. Se o falante não sabe que $p$, então o ouvinte não pode vir a saber que $p$, com base no testemunho do falante. Uma condição necessária para que o ouvinte venha a saber que $p$ com base no testemunho é que o falante saiba que p. Audi ilustra essa posição, quando afirma o seguinte:

\begin{abstract}
"Testemunho pode dar conhecimento aos seus ouvintes apenas sob determinadas condições. Se eu não sei que o orador na conferência de ontem perdeu a calma, então você não pode vir a sabê-lo com base na minha declaração. Isso é óbvio, se eu estou enganado e ele de fato não perdeu a calma. Todavia, suponha que eu faço uma suposição afortunada e essa esteja correta. Nesse caso, eu lhe dou a informação correta, informação conjecturada da qual não tenho conhecimento; e você também por sorte está correto, mas também não sabe que ele [o orador] perdeu a calma." (AUDI, 2003, p. 137).
\end{abstract}

A ideia que subjaz à passagem acima é que aquilo que eu não tenho eu não posso dar. Uma formulação dessa tese poderia ser a seguinte: para um falante $\mathrm{A}$ e um ouvinte B, B sabe que $p$ com base no testemunho de A de que $p$ se e somente se A sabe que $p$.

Se por conhecimento compreendemos crença verdadeira mais alguma(s) propriedade(s) epistêmica(s) que converte $(\mathrm{m})$ crença verdadeira em conhecimento, então, para que um falante A saiba que $p$, o falante $\mathrm{A}$ tem de crer que $p$. A condição da crença é uma condição necessária para o conhecimento. Se, para um falante A e um ouvinte B, B sabe que $p$ com base no testemunho de $\mathrm{A}$ de que $p$ se e somente se $\mathrm{A}$ sabe que $p$, então se A não crê que $p$, B não pode vir a saber que $p$ com base no testemunho de A. Todavia, considere o seguinte caso proposto por Jennifer Lackey: 
"Caso da Professora Criacionista: Stella é uma professora da quarta série, que é cristã devota, e suas crenças religiosas estão baseadas em uma fé profunda que ela tem desde que era muito jovem. Parte da sua fé inclui uma crença na verdade do Criacionismo e, consequentemente, uma crença na falsidade da Teoria Evolucionista. Apesar disso, ela reconhece plenamente que existe uma enorme quantidade de evidência científica contra essas duas crenças. Na verdade, ela admite não estar baseando o seu comprometimento com o Criacionismo completamente nas evidências, mas na fé pessoal que ela tem em um Criador todopoderoso. Devido a isso, Stella não acha que a religião seja algo que ela deve impor àqueles que estão ao seu redor, e isso é especialmente verdadeiro com relação a seus alunos da quarta série. Em vez disso, ela considera seu dever como professora incluir no material que apresenta aquele que está melhor sustentado pelas evidências disponíveis, que inclui claramente a verdade da Teoria Evolucionista. Como resultado, após consultar fontes fidedignas na biblioteca e desenvolver notas de aula confiáveis, Stella afirma aos seus alunos "O Homo sapiens moderno evoluiu do Homo erectus", ao apresentar a sua aula de biologia hoje. Apesar de Stella não crer nem saber essa proposição, ela não compartilha as suas próprias opiniões pessoais, que estão baseadas na fé, com seus alunos, e assim eles formam a crença verdadeira correspondente unicamente com base no seu testemunho confiável." (LACKEY, 2008, p. 48).

Se o caso acima funciona como contra-exemplo para o requerimento de conhecimento, então um falante pode ser uma fonte confiável e transmitir informações verdadeiras sem, no entanto, crer nessas informações. O professor não tem conhecimento porque não satisfaz a condição da crença. Se os casos que vimos acima funcionam, então precisamos reformular a definição inicial do não-reducionismo acerca do conhecimento testemunhal, a fim de incluir uma cláusula que garanta a conducência à verdade.

$\mathrm{NR}^{2}$ : $\quad$ Para um falante A e um ouvinte B, B sabe que $p$ por causa e com base no testemunho de $A$ de que $p$ se e somente se:

$\left(\mathrm{NR}_{1}\right) \quad$ B crê que $p$ por causa e com base no testemunho de $\mathrm{A}$ de que $p$;

$\left(\mathrm{NR}_{2}\right) \quad B$ não tem qualquer derrotador não-derrotado (psicológico ou normativo) para o testemunho de A de que $p$;

$\left(\mathrm{NR}_{3}\right)$ é fato que $\mathrm{p}$; e

$\left(\mathrm{NR}_{4}\right)$ a fonte e a base testemunhais são suficientemente conducentes à verdade.

Considere que a exigência $\left(\mathrm{NR}_{4}\right)$ requer que o desempenho do falante tenha alguma propriedade conducente à verdade. Lembre-se que uma implicação de NR era que qualquer relato verdadeiro de qualquer falante 
poderia proporcionar conhecimento testemunhal para qualquer ouvinte, caso não haja algum derrotador não-derrotado. Agora, nem todo falante pode ser um candidato a promover conhecimento testemunhal, apenas aqueles cujo desempenho é suficientemente conducente à verdade.

Entretanto, um falante com um desempenho suficientemente conducente à verdade pode proporcionar conhecimento testemunhal para qualquer ouvinte, caso não haja algum derrotador não-derrotado? Lembrese, a visão apresentada por $\mathrm{NR}^{2}$ ainda sugere uma grande abrangência. Concentrar-me-ei agora em considerar o papel do ouvinte, de qualquer ouvinte. Uma criança ou um adulto, uma pessoa mais ou menos informada, ou ainda, uma pessoa com maior ou menor habilidade cognitiva poderia exemplificar o papel requerido para qualquer ouvinte.

Considere, agora, o caso do ouvinte otimista. Suponha que você está conduzindo o seu carro em direção ao litoral, mas não sabe onde fica a entrada da praia em que deseja veranear. De repente, à margem da estrada, você avista alguém (um estranho), pára o carro e pergunta: "Onde é a entrada para a praia...?". Ocorre que o sujeito lhe fornece a informação p. Nesse caso, o informante é o prefeito da praia que você procura e é uma pessoa de grande credibilidade para os cidadãos da cidade; é alguém cujo desempenho como falante é suficientemente conducente à verdade. Naquela situação, você passa a crer que $p$ por causa e com base no que ele lhe disse e não tem qualquer derrotador invicto. Suponha, ainda, que seja fato que $p$. Todavia, suponha que você seja um otimista epistêmico irresistível. Ocorre que você sempre superestima a avaliação que faz sobre a credibilidade do informante ou da probabilidade de $p$ ser verdadeira. Nessa ocasião, você não tem qualquer crença ou evidência disponível para não crer na declaração do informante (o prefeito) de que $p$ ou, ainda, crer que $p$ é falsa. O testemunho do informante (o prefeito) é de fato digno de crédito, mas você creria mesmo se não fosse, porque você tem uma sensibilidade defectiva em relação aos derrotadores.

O primeiro aspecto a considerar no caso do ouvinte otimista é que o fato de você superestimar a avaliação que faz sobre a credibilidade do informante ou da probabilidade de $p$ ser verdadeira torna você basicamente uma pessoa crédula. Entretanto, a ideia básica do nãoreducionismo é a de ser irrepreensível ao crer. Pense! Crer ou deixar de crer de acordo com a própria consciência epistêmica parece salvaguardar a idéia de integridade intelectual. A consciência epistêmica compreende aquelas convicções mais fundamentais armazenadas, na qual o sujeito mantém o sentido de sua integridade intelectual. Todavia, não é necessário que as convicções epistêmicas fundamentais do sujeito sejam verdadeiras, embora o objetivo seja esse. Assim, diferentes sujeitos podem ter diferentes consciências. Não crer contra a própria consciência 
epistêmica parece ser a regra mais próxima e mais segura ao próprio sujeito, para crer racionalmente. Se o sujeito crê contra sua consciência epistêmica, a sua atitude doxástica será considerada repreensível. Violar as exigências de sua própria consciência significa violar a própria integridade intelectual.

Se o ouvinte crê ou deixa de crer segundo a sua própria consciência epistêmica, ainda que tenha uma consciência epistêmica defectiva, resguarda a sua integridade intelectual. O fato de a consciência epistêmica ser defectiva, no sentido de torná-lo crédulo, gera uma grande lacuna entre a sua consciência epistêmica e o ideal epistêmico. Contudo, ainda que as convicções fundamentais do ouvinte sejam falsas e suas habilidades epistêmicas sejam defectivas, é fundamental lembrar que o que salvaguarda o ideal epistêmico é a satisfação da condição $\mathrm{NR}_{4}$. Enquanto a satisfação da condição $\mathrm{NR}_{2}$ salvaguarda a sua integridade intelectual ou o torna irrepreensível epistemicamente, a satisfação da condição $\mathrm{NR}_{4}$ salvaguarda a conducência à verdade. Não vejo por que seja necessário que o ouvinte tenha que ter um padrão de consciência epistêmica ou ter qualquer habilidade epistêmica particular. No caso acima, satisfeitas as condições $\mathrm{NR}_{1}-\mathrm{NR}_{4}$, ainda que o ouvinte superestime a avaliação que faz sobre a credibilidade do informante ou da probabilidade de $p$ ser verdadeira, ele sabe que $p$. Se um padrão de consciência epistêmica ou alguma habilidade epistêmica particular fossem requeridos ao ouvinte, no sentido de garantir um padrão intelectual mais alto ou uma sensibilidade mais acurada aos derrotadores, isso consequentemente excluiria as crianças. Afinal, crianças pequenas nem sequer têm o conceito de credibilidade e outras noções habilidade epistêmicas suficientemente desenvolvidas para poderem satisfazer um padrão de sensibilidade mais acurado em relação aos derrotadores. Entretanto, crianças em seus primeiros anos de vida dependem quase totalmente do testemunho de seus pais, benfeitores e tutores para aprender sobre o mundo. Estabelecer uma cláusula para que a atitude epistêmica do ouvinte seja suficientemente conducente à verdade parece ser excessiva nesse caso. Assim, no caso do ouvinte otimista, você crê que $p$ com base no testemunho do informante (prefeito), cujo desempenho como falante é suficientemente conducente à verdade e salvaguarda a sua integridade intelectual. Você satisfaz as condições $\mathrm{NR}_{1}-\mathrm{NR}_{4}$ e, portanto, sabe que $p$.

Considere, agora, um caso alternativo, o caso do ouvinte pessimista. Suponha que você esteja conduzindo o seu carro em direção ao litoral, mas não sabe onde fica a entrada da praia em que deseja veranear. De repente, à margem da estrada, você avista alguém (um estranho), pára o carro e pergunta: "Onde é a entrada para a praia...?". Ocorre que o sujeito lhe fornece a informação $p$. Nesse caso, o informante é o prefeito 
da praia que você procura e é uma pessoa de grande credibilidade para os cidadãos da cidade; é alguém cujo desempenho como falante é suficientemente conducente à verdade. Suponha, ainda, que seja fato que $p$. Todavia, suponha que você seja, agora, um pessimista epistêmico irresistível. Ocorre que você sempre subestima a avaliação que faz sobre a credibilidade do informante ou da probabilidade de $p$ ser verdadeira. Nessa ocasião, você crê (injustificadamente) que a declaração do informante (o prefeito) de que $p$ não é digna de crédito e que a informação oferecida provavelmente é falsa. O fato é que o testemunho do informante (o prefeito) é digno de crédito, mas as suas crenças funcionam como um filtro e, por causa delas, você não crê que $p$. Afinal, você tem uma sensibilidade defectiva em relação aos derrotadores.

O caso do ouvinte pessimista é semelhante ao caso do ouvinte otimista. O problema, nesse caso, é que o ouvinte subestima a avaliação que faz sobre a credibilidade do informante ou da probabilidade de $p$ ser verdadeira. Essa atitude por parte do ouvinte tenderá a levá-lo a uma posição cética. Entretanto, se o ouvinte crê ou deixa de crer segundo a sua própria consciência epistêmica, ainda que tenha uma consciência epistêmica defectiva, resguarda a sua integridade intelectual.

De acordo com Roderick Chisholm (1977, p. 14), como seres racionais nós devemos tentar fazer o melhor possível para alcançar o fim epistêmico de crer em verdades e não crer em falsidades. Essa visão deriva da compreensão jamesiana do ideal epistêmico. Entretanto, em sua célebre passagem, William James afirma: "Acredite na verdade! Evite o erro! essas, vemos, são duas leis materialmente diferentes; e, por escolher dentre as mesmas, podemos terminar por colorir diferentemente toda a nossa vida intelectual" (JAMES, 1967, p. 242-243). Dois pontos devem ser considerados nessa passagem. Primeiramente, há dois fins epistêmicos, e não um só. Em segundo lugar, o tipo de mescla adotada para a combinação desses dois fins indicará a perspectiva da vida intelectual de um agente. Afinal, alguém pode priorizar "crer em verdades" em relação a "evitar o erro"; ou, ainda, "evitar o erro" como atitude fundamental e "crer em verdades" como uma ampliação. Portanto, mesmo a busca do ideal epistêmico permite algumas variações. Nesse sentido, o ouvinte pode tender tanto a crer em verdades quanto a evitar crer em falsidades.

No caso do ouvinte pessimista, as condições $\mathrm{NR}_{1}$ e $\mathrm{NR}_{2}$ não foram satisfeitas. Ainda que o ouvinte tenha subestimado a avaliação que fez sobre a credibilidade do informante ou da probabilidade de $p$ ser verdadeira, porque tem um comportamento epistêmico defectivo em relação aos derrotadores, a sua integridade epistêmica foi resguardada. O grande desafio do não-reducionismo é assegurar que a fonte e a base da crença sejam conducentes à verdade e, ademais, assegurar a 
inviolabilidade da integridade intelectual do agente epistêmico. Dado o exposto, a versão $\mathrm{NR}^{2}$ do não-reducionismo sobre conhecimento testemunhal parece satisfazer esses requisitos.

\section{Considerações finais}

Vimos que as condições sociais oferecem uma base ao conhecimento. Afinal, as pessoas não podem adquirir muito conhecimento sem a linguagem socialmente dada. Não só a aquisição da competência linguística depende da ajuda dos outros, mas também o próprio conceito de conhecimento. Os relatos que as pessoas oferecem cotidianamente sobre si mesmas e sobre o mundo são responsáveis por grande parte das crenças que formamos e retemos. Deve ser lembrado que crianças em seus primeiros anos de vida dependem quase totalmente dos outros para aprender sobre o mundo. Mesmo que possamos adquirir muito conhecimento por meio da percepção e do raciocínio, por exemplo, parece difícil pensar a vida cotidiana sem o testemunho.

Indicamos que o interesse pelo estatuto epistêmico do testemunho foi aumentando durante os séculos 17 e 18 e ele que pode ser localizado, sobretudo, nos escritos de David Hume e Thomas Reid. Em nossos dias, a discussão polarizou-se entre reducionistas e não-reducionistas. Os reducionistas, cujas raízes históricas remontam a David Hume, requerem que uma base não-testemunhal suficiente seja oferecida pelo agente epistêmico. Os não-reducionistas, cujas raízes históricas remontam a Thomas Reid, não requerem uma base não-testemunhal suficiente, desde que não exista qualquer base epistêmica para a dúvida.

Avaliamos de modo particular a visão não-reducionista acerca do conhecimento testemunhal. Partimos de uma visão inicial do nãoreducionismo cuja característica fundamental era que qualquer relato verdadeiro de qualquer falante poderia proporcionar conhecimento testemunhal para qualquer ouvinte, caso não houvesse algum derrotador não-derrotado. Concentramo-nos inicialmente em avaliar um relato verdadeiro de qualquer falante e compreendemos que (a) nem todo falante pode cumprir um papel epistêmico adequado, (b) que requerer conhecimento do falante não é suficiente, (c) que requerer conhecimento do falante também não é necessário, mas (d) que somente aqueles falantes que têm um desempenho epistêmico suficientemente conducente à verdade podem cumprir um papel epistêmico adequado ao dar testemunho. Concentramo-nos posteriormente em avaliar o papel do ouvinte, de qualquer ouvinte, e compreendemos que ainda que o ouvinte creia ou deixe de crer segundo a sua própria consciência epistêmica, ainda que tenha uma consciência epistêmica defectiva, a condição $\mathrm{NR}_{2}$ 
resguarda a sua integridade intelectual. Nenhuma outra condição deve ser requerida do ouvinte. Concluímos que pelo menos dois requerimentos devem ser salvaguardados pelo não-reducionismo: (i) um desempenho epistêmico conducente à verdade por parte do falante e (ii) a integridade intelectual do ouvinte.

\section{Referências}

AUDI, R. Epistemology: A Contemporary Introduction to the Theory of Knowledge. London: Routledge, ${ }^{2} 2003$.

CHISHOLM, R. Theory of Knowledge. Englewood Cliffs, N.J.: Prentice-Hall, ${ }^{2} 1977$.

COADY, C. A. J. Testimony: A Philosophical Study. Oxford: Clarendon Press, 1992.

FOLEY, R. Intellectual Trust in Oneself and Others. Cambridge: Cambridge University Press, 2001.

FRICKER, E. Testimony. In: AUDI, R. (ed.). The Cambridge Dictionary of Philosophy. Cambridge: Cambridge UP, ${ }^{2} 1999$.

HUME, D. Investigação sobre o entendimento humano. São Paulo: Nova Cultural, 2000 .

JAMES, W. Pragmatismo e outros ensaios. Rio de Janeiro: Lidador, 1967.

LACKEY, J. Learning from Words: Testimony as a Source of Knowledge. Oxford: Oxford University Press, 2008.

LOCKE, J. Ensaios sobre o entendimento humano. Lisboa: FCG, 1999.

REID, T. Thomas Reid's Inquiry and Essays. Indianapolis: Hackett, 1983.

SCHMITT, F. Social Epistemology. In: GRECO, J. and SOSA, E. (eds.). The Blackwell Guide to Epistemology. Oxford: Blackwell Publishers, 1999, p. 354-382.

SCHMITT, F. Socializing Epistemology: An Introduction through Two Sample Issues. In: SCHMITT, F. (ed.). Socializing Epistemology. Lanham, MD: Roman and Littlefield, 1994. p. 1-27.

WOLTERSTORFF, N. Thomas Reid and the Story of Epistemology. Cambridge: Cambridge UP, 2001. 